\title{
Effects of ligature-induced periodontitis in pregnant Wistar rats
}

\section{Efeito da doença periodontal induzida por ligadura na prenhez de ratas Wistar}

\author{
Mariane Ponzio de Azevedo Galvão* \\ Cassiano Kuchenbecker Rösing** \\ Maria Beatriz Cardoso Ferreira***
}

\begin{abstract}
The aim of this study was to evaluate the influence of ligature-induced periodontal disease in pregnant rats on their newborn's health parameters. Twenty-four female adult Wistar rats were divided into two groups: the control group (G1) and the group that was submitted to dental ligatures around second upper molars (G2). After the four week period of development of periodontitis, the female animals were mated with male adult Wistar rats. There were no differences in the body weight of females between the two groups during mating and pregnancy. No differences were observed among the groups in relation to the viable newborn index. However, there were differences in newborn birth weight, explained by the diverse size of the litters. In this study, ligature-induced periodontal disease did not promote changes during pregnancy that resulted in low birth weight in newborn Wistar rats.

DESCRIPTORS: Periodontitis; Labor, premature; Infant, low birth weight; Wistar rats.
\end{abstract}

RESUMO: O objetivo do presente estudo foi avaliar a influência da periodontite induzida por ligadura em ratas prenhes sobre parâmetros de saúde geral de seus filhotes. Vinte e quatro ratas Wistar de idade adulta foram divididas em dois grupos: grupo controle $(\mathrm{G} 1)$ e grupo experimental, que recebeu ligaduras ao redor dos segundos molares superiores (G2). Após o período de indução de periodontite (quatro semanas), as ratas foram colocadas para cruzamento com ratos Wistar machos, adultos. Não houve diferença no peso corporal das fêmeas durante os períodos de cruzamento e prenhez. Também não foram observadas diferenças entre os grupos quanto à taxa de recém-nascidos viáveis. No entanto, houve diferença quanto ao peso dos recém-nascidos, sendo tal diferença explicada pela variação no tamanho das ninhadas. No presente estudo, doença periodontal induzida por ligadura não promoveu mudanças durante a prenhez que resultassem em baixo peso ao nascer dos filhotes Wistar.

DESCRITORES: Periodontite; Trabalho de parto prematuro; Recém-nascido de baixo peso; Ratos Wistar.

\section{INTRODUCTION}

Recent research has shown an association between periodontal disease and systemic disturbances ${ }^{2,13,20,26,27}$. Special attention has been paid to the association between periodontal disease and preterm low birth weight $\mathrm{t}^{4,5,6,7,19,20,21}$.

An experimental study ${ }^{6}$ has shown that the inoculation of Porphyromonas gingivalis in a subcutaneous chamber in female hamsters was able to promote a significant decrease in fetal weight and significant increase in embryolethality rates. This study also showed the presence of inflammatory mediators prostaglandin $\mathrm{E}_{2}\left(\mathrm{PGE}_{2}\right)$ and tumor necrosis factor $\alpha(\mathrm{TNF} \alpha)$ at higher levels in the subcutaneous chamber, after the inoculation of Porphyromonas gingivalis. A significant association was found between high levels of these inflammatory mediators and low fetal weight and embryolethality ${ }^{6}$. Following these experiments, it has been shown that the intravenous challenge of lipopolysaccharide (LPS) of Porphyromonas gingivalis and Escherichia coli in hamsters, before and after mating, lead to a significant decrease in fetal weight ${ }^{5}$. Hamsters fed with sucrose rich diet, with or without inoculation with Porphyromonas gingivalis, developed periodontitis. After periodontitis was established, the animals were mated and the results showed a reduction of $17.4 \%$ of fetal weight when compared to control animals ${ }^{4}$.

A case-control study ${ }^{20}$ in humans has shown that mothers with $60 \%$ of periodontal sites with at least three millimeters of attachment loss had a 7.5 times higher chance of having babies with low birth weight than controls. Many studies have focused on the association between periodontal pathology and pregnancy problems in humans ${ }^{7,8}$. Higher levels of $\mathrm{PGE}_{2}$ in the crevicular fluid were seen more frequently in the mothers of low birth weight newborns ${ }^{19}$. Recent investigation showed

* Professor, Discipline of Periodontics, Gama Filho University.

** Professor, Discipline of Periodontics; ***Professor, Department of Pharmacology - Federal University of Rio Grande do Sul. 
Galvão MP de A, Rösing CK, Ferreira MBC. Effects of ligature-induced periodontitis in pregnant Wistar rats. Pesqui Odontol Bras 2003;17(1):51-5.

the presence of fetal immunoglobulins against periodontal pathogens, suggesting a possible bacterial challenge in the uterus ${ }^{21}$.

Although evidence for the association between periodontal disease and low birth weight is accumulating with numerous experimental and clinical reports, this field still lacks experimental investigations to elucidate a cause-and-effect relationship.

The aim of this study was to evaluate the influence of induced periodontal disease in pregnant rats in newborn's health parameters.

\section{MATERIALS AND METHODS Animals}

Twenty-four experimentally naïve adult female Wistar rats (60 days old) were divided in two equal experimental groups. The control animals (Group 1) received standard rat laboratory chow and water. In the Group 2, or the ligature-induced periodontal disease group, cotton ligatures were placed around the second upper molars, and the animals received standard rat laboratory chow and water.

Eight experimentally naïve adult male Wistar rats (60 days old) were used to mate with the female animals. The rats born after this match were also studied.

\section{Induction of periodontal disease}

To induce periodontal disease, cotton ligatures were placed around the second upper molars, in rats from Group 2. All rats, even those from Group 1 , received general anesthesia with sodium thiopental at the time of ligature placement. A period of one month was established for the development of periodontitis, during this time the presence of ligatures was checked every week ${ }^{12,24,25,29}$. The ligatures were kept until the last day of breast feeding, when the mothers were sacrificed, the maxillae were removed, fixed, decalcified with 5\% nitric acid, and sectioned serially at $5 \mu \mathrm{m}$ in the mesiodistal direction. The sections were stained with hematoxylin-eosin. As part of another experimental research, a trained examiner who was blind to the groups carried out descriptive histological analysis in the light microscope. The histological features of 220 histological pieces showed that samples from Group 1 (without ligatures) had no signs of inflammation (intact sulcular epithelium with standard dimensions; standard quantity of tissue cells and blood vessels; dense supracrestal and periodontal fibers and regular alveolar bone crests), while samples from Group 2 (with ligatures) showed signs of inflammation (long junctional epithelium; overabundance of connective tissue cells and blood vessels; loose supracrestal and alveolar fibers; irregular alveolar bone crest with Howship's lacunae).

\section{Frequency of evaluation}

The body weight of the mother rats was evaluated during all the experiment, at a frequency of three times per week. Newborns were checked on the day of birth and three times per week until they reached the age of 60 days.

\section{Health parameters}

Body weight from mothers and young rats was measured. Right after birth, the number of young rats per litter, the number of viable young animals per group, and the mean body weight per group were evaluated. The number of viable young animals was measured as the number of viable newborns divided by the total of newborns multiplied by 100 , for each litter.

\section{Statistical analysis}

Data were expressed as mean and standard deviation (SD). Student's t-test was used to compare between two groups. Repeated comparisons were analyzed by repeated measures (ANOVA). Linear regression was used to analyze the influence of litter size over newborn weight.

\section{RESULTS}

The mothers' health parameters are shown in Graphs 1 and 2. No statistically significant difference was observed in body weight between the two groups, at the different times of evaluation during periodontal disease induction, gestation, after delivery, and during breastfeeding periods (one-way ANOVA, $p>0.05$ ).

Table 1 shows the mean and standard deviation of the total number of babies per litter and the viable babies. There were significant differences between the groups in relation to the total number of babies per litter (Student's $t$-test, $\mathrm{p}=0.05$ ), and no difference in relation to viable babies (Student's $t$-test, $\mathrm{p}>0.05)$. The body weight of babies at birth and after breastfeeding is shown in Table 2, where we can observe statistically significant differences (Student's $t$-test, $\mathrm{p}<0.05$ ). The number of babies differed between the time of birth and the time after breastfeeding, as some were sacrificed with the 
Galvão MP de A, Rösing CK, Ferreira MBC. Effects of ligature-induced periodontitis in pregnant Wistar rats. Pesqui Odontol Bras $2003 ; 17(1): 51-5$.

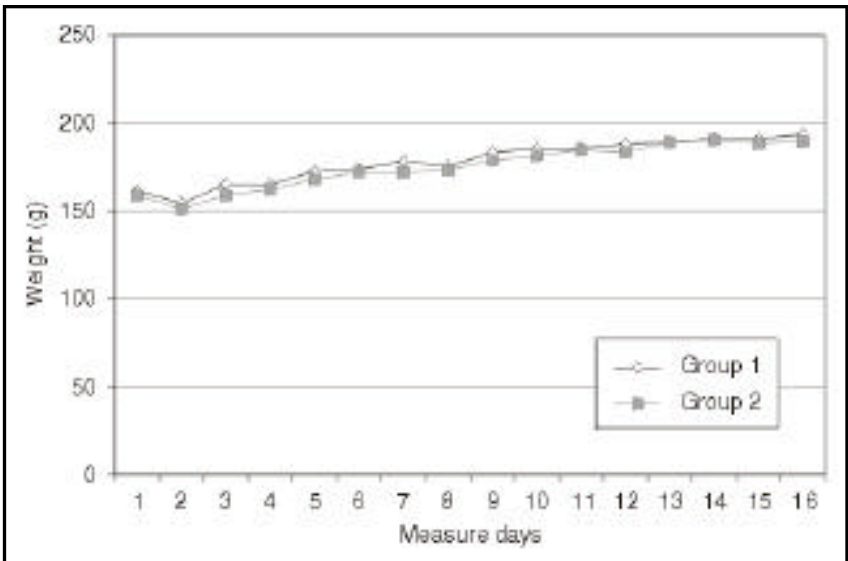

GRAPH 1 - Mother's body weight during induction of periodontal disease (mean). Group 1: control; Group 2: ligature.

TABLE 1 - Mean number (n) of young rats per litter and number of viable baby animals per litter (mean $\pm \mathrm{SD}$ ).

\begin{tabular}{c|c|c|c}
\hline \hline Group & $\mathrm{n} /$ litter & $\begin{array}{c}\text { Number of } \\
\text { babies }^{\mathrm{a}}\end{array}$ & $\begin{array}{c}\text { Number of } \\
\text { viable babies } \\
(\%)^{\mathrm{b}}\end{array}$ \\
\hline $\mathrm{G} 1$ - control & 11 & $12.00 \pm 2.05$ & $98.45 \pm 3.50$ \\
\hline $\mathrm{G} 2$ - ligature & 11 & $10.00 \pm 2.45$ & $98.90 \pm 3.62$ \\
\hline \hline
\end{tabular}

SD: standard deviation. aSignificant difference between groups (Student's $t$-test, $\mathrm{p}=0.05$ ). bNo significant difference between groups (Student's $t$-test, $\mathrm{p}=0.76$ ).

TABLE 3 - Body weight of female and male baby rats at 60 days of life (mean $\pm \mathrm{SD}$ ).

\begin{tabular}{l|c|c|c|c}
\hline \hline Group & $\begin{array}{c}\mathrm{n} \\
(\text { female })\end{array}$ & $\begin{array}{c}\text { Body } \\
\text { weight }(\mathrm{g})^{\mathrm{a}}\end{array}$ & $\begin{array}{c}\mathrm{n} \\
(\text { male })\end{array}$ & $\begin{array}{c}\text { Body } \\
\text { weight }(\mathrm{g})^{\mathrm{b}}\end{array}$ \\
\hline $\begin{array}{l}\mathrm{G} 1- \\
\text { control }\end{array}$ & 34 & $172.82 \pm 5.90$ & 32 & $255.94 \pm 24.98$ \\
\hline $\begin{array}{l}\text { G2 - } \\
\text { ligature }\end{array}$ & 30 & $179.63 \pm 26.55$ & 35 & $261.22 \pm 23.22$ \\
\hline \hline
\end{tabular}

$\mathrm{SD}$ : standard deviation; $\mathrm{n}$ : number. aThere is no significant difference among groups (Student's $t$-test, $\mathrm{p}=0.34)$. bThere is no significant difference among groups (Student's $t$-test, $\mathrm{p}=0.52$ ).

aim of keeping the litter with the same number of newborns ${ }^{1}$. No significant difference was seen between the groups, in relation to the baby's body weight at 60 days of life (Table 3).

\section{DISCUSSION}

The literature suggests a relationship between periodontal disease and systemic

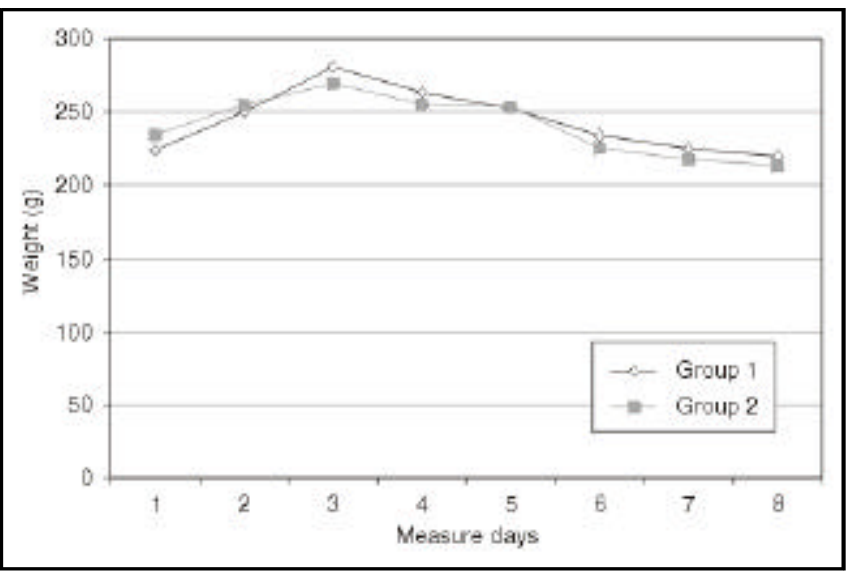

GRAPH 2 - Mother's body weight during the period of breastfeeding (21 days) (mean). Group 1: control; Group 2: ligature.

TABLE 2 - Body weight of the baby rats at birth and after breastfeeding period (mean $\pm \mathrm{SD}$ ).

\begin{tabular}{c|c|c|c|c}
\hline \hline Group & $\mathrm{n}$ & $\begin{array}{c}\text { Body weight } \\
\text { at birth }(\mathrm{g})^{\mathrm{a}}\end{array}$ & $\begin{array}{c}\mathrm{n} \\
\text { (young) }\end{array}$ & $\begin{array}{c}\text { Difference of } \\
\text { body weight } \\
\text { between birth } \\
\text { and 2 } \text { st day of }^{\text {life }(\mathrm{g})^{\mathrm{b}}}\end{array}$ \\
\hline $\mathrm{G} 1-$ control & 132 & $5.57 \pm 0.52$ & 66 & $39.50 \pm 5.59$ \\
\hline $\mathrm{G} 2-$ ligature & 110 & $5.90 \pm 0.49$ & 65 & $41.67 \pm 4.36$ \\
\hline \hline
\end{tabular}

SD: standard deviation. aStatistically significant difference (Student's $t$-test, $\mathrm{p}=0.000$; by linear logistic regression, controlling for litter size, $p=0.032$ ). bStatistically significant difference (Student's $t$-test, $\mathrm{p}=0.02)$.

pathologies $2,16,20,26,27$, including preterm low birth weight problems s, $^{7,8,19,20,21}$.

This study was designed to uncover possible relations between periodontal disease induced in rats and preterm low birth weight. To induce periodontal disease in the future mother rats, cotton ligatures were used around the second upper molars ${ }^{12,24,25,29}$. The placement of a ligature around the rat's molars promote an inflammatory challenge with the presence of neutrophils, T- and B-lymphocytes, ulceration and apical migration of epithelial attachment ${ }^{14}$. As previous studies have shown impossibility of promoting periodontitis by placement of ligatures in germ-free rats or in rats under antibiotic therapy, it may be concluded that ligature-induced periodontal disease only occurs in the presence of bacteria ${ }^{24,25}$. In conventional rats, early plaque is dominated by streptococci, but as plaque thickness increases, Gram-negative 
Galvão MP de A, Rösing CK, Ferreira MBC. Effects of ligature-induced periodontitis in pregnant Wistar rats. Pesqui Odontol Bras 2003;17(1):51-5.

and anaerobic organisms become more prominent and Bacteroides species are seen in one-month-old $\operatorname{rats}^{14}$.

There was no significant difference between groups concerning the mother's weight, in the beginning of the experiment or during periodontal disease induction, pregnancy and breastfeeding periods, which mean that the induction of treatments did not bias the results. These parameters are recognized as influencing treatment and health conditions ${ }^{9,11}$.

There was no significant difference between groups in relation to the number of viable youngsters ${ }^{28}$, suggesting that the treatments did not change the mortality number at birth. This result is in disagreement with a previous study ${ }^{6}$, where it was observed that periodontal pathogens (Porphyromonas gingivalis) injected in subcutaneous chamber in hamsters promoted embryolethality. That study found less newborns per litter in hamsters that received Porphyromonas gingivalis, compared to controls. Another experimental study ${ }^{5}$ showed that the sublingual venous injection of $30 \mu \mathrm{g}$ of Escherichia coli lipopolysaccharide in pregnant hamsters was able to kill the fetus, with some animals showing uterus discharge. The authors suggested that oral bacteria would be able to change the uterus homeostasis. From their results, it may be supposed that bacterial injection in animals may promote uterus alterations, which could be the reason for fetus death. Uterus and kidney infections are known to cause preterm low birth weight in human beings ${ }^{10,15,17,18,22,23}$. The differences found between these experimental studies and ours may be related to the different animal species utilized, rats versus hamsters. Moreover, the bacteria challenge was different. The subcutaneous or intravenous inoculation of periodontal pathogens may represent an acute and specific microbial challenge, and may result in a much more intense systemic response, which could alter the pregnancy outcome. In the ligature model, periodontal destruction was observed, but the systemic reaction was

\section{REFERENCES}

1. Alder S, Zbinden G. Methods for the evaluation of physical, neuromuscular, and behavioral development of rats in early postnatal life. In: Neubert D, Merker HJ, Kwasigroch TE. Methods in prenatal toxicology. Evaluation of embryo- probably lower. The mean birth weight in the present study was higher in the group with ligatures. This finding is different from the literature. This difference could result from the fact that this group had less newborns per litter, with statistical significance when compared to the other group. The difference between this finding and the two experimental studies shown in the literature ${ }^{5,6}$ may be related to the different challenge promoting the periodontal disease condition. The previous studies were able to observe preterm low birth weight when hamsters were inoculated with periodontal pathogens, however periodontal inflammation caused by cotton ligatures was not enough to promote preterm low birth weight in Wistar rats in the present experiment.

Based on the medical literature ${ }^{3,10,23}$, it has been speculated that periodontitis in pregnant women may enhance the bacterial or inflammatory mediator challenge which can get into the blood stream and cause preterm membrane rupture and birth, and as a consequence low birth weight. Offenbacher et al. ${ }^{19}$ (1998) found higher levels of $\mathrm{PGE}_{2}$ and $\mathrm{TNF} \alpha$ in the amniotic fluid of animals with periodontitis.

In contrast to what the literature speculates ${ }^{4,5,6}$, it was observed in the present study that periodontal disease induced by ligature promoted no alterations in pregnant rats, and neither caused preterm low birth weight. There was no effect of the treatment - ligature - upon the body weight of mother rats during the different experimental periods. The number of newborns was higher in the control group. But the number of viable newborns was similar between the different groups. At birth and after breastfeeding lag, the newborns from mothers submitted to periodontal induction with ligature had the highest mean birth weight, but this was influenced by litter size.

\section{CONCLUSION}

The relation of cause and effect between periodontitis and preterm low birth weight has not been shown in the present study, according to the methodology of this experiment.

toxic effects in experimental animals. Stuttgart: Georg Thiene; 1977. p.175-85. 
Galvão MP de A, Rösing CK, Ferreira MBC. Effects of ligature-induced periodontitis in pregnant Wistar rats. Pesqui Odontol Bras 2003;17(1):51-5.

2. Beck JD, Offenbacher S, Williams R, Gibbs P, Garcia R. Periodontitis: a risk factor for coronary heart disease? Ann Periodontol 1998;3:127-41.

3. Bejar R, Curbelo V, Davis C, Gluck L. Premature labor. II. Bacterial sources of phospholipase. Obstet Gynecol 1981;57:479-82.

4. Collins JG, Kirtland BC, Arnold RR, Offenbacher, S. Experimental periodontitis retards hamster fetal growth [abstract 1117]. J Dent Res 1995;74:158.

5. Collins JG, Smith MA, Arnold RR Offenbacher S. Effects of Escherichia coli and Porphyromonas gingivalis on pregnancy outcome in the golden hamster. Infect Immun 1994;62:4652-5.

6. Collins JG, Windley $3^{\text {rd }}$ HW, Arnold RR, Offenbacher S. Effects of a Porphyromonas gingivalis infection on inflammatory mediator response and pregnancy outcome in hamsters. Infect Immun 1994;62:4356-61.

7. Damaré SM, Maynor G, Jenzano J, Katz V, Offenbacher S. Relationship between periodontal and amniotic fluid inflammatory mediators in pregnancy [abstract 1173]. J Dent Res 1995;74:158.

8. Dasanayake AP. Poor periodontal health of the pregnant woman as a risk factor for low birth weight. Ann Periodontol 1998;3:206-12.

9. Frohberg H. An introduction to research in teratology. In: Neubert D, Merker HJ, Kwasigroch TE. Methods in prenatal toxicology. Evaluation of embryotoxic effects in experimental animals. Stuttgart: Georg Thiene; 1977. p.1-13.

10. Gibbs RS, Romero MD, Hillier SL, Eschenbach DA, Sweet RL. A review of premature birth and subclinical infection. Am J Obstet Gynecol 1992;166:1515-28.

11. Grauwiler J, Leist KH. A schedule for examination of postnatal development in rats. In: Neubert D, Merker HJ, Kwasigroch TE. Methods in prenatal toxicology. Evaluation of embryotoxic effects in experimental animals. Stuttgart: Georg Thiene; 1977. p.166-74.

12. Györfi A, Fazekas Á, Suba ZS, Ender F, Rosivall L. Neurogenic component in ligature-induced periodontitis in the rat. J Clin Periodontol 1994;21:601-5.

13. Hayes C, Sparrow D, Cohen M, Vokonas PS, Garcia RI. The association between alveolar bone loss and pulmonary function: the VA Dental Longitudinal Study. Ann Periodontol 1998;3:257-61.

14. Klausen B. Microbiological and immunological aspects of experimental periodontal disease in rats: a review article. $J$ Periodontol 1991;62:59-73.

15. Møller M, Borch K, Thomsen AC, Dinesen K, Zdravkovic M. Rupture of fetal membranes and premature delivery associated with group B streptococci in urine of pregnant women. Lancet 1984;2:69-70.
16. Mattila KJ, Valtonen VV, Nieminen MS, Huttunen JK. Dental infection and the risk of new coronary events: prospective study of patients with documented coronary artery disease. Clin Infect Dis 1995;20:588-92.

17. McDonald HM, O'Loughlin JÁ, Jolley R, Vigneswaran R, McDonald PJ. Vaginal infection and preterm labour. Br J Obstet Gynaecol 1991;98:427-35.

18. Minkoff H, Grunebaum AN, Schwarz RH, Feldman J, Cummings $\mathrm{M}$, Crombleholme $\mathrm{W}$, et al. Risk factors for prematurity and premature rupture of membranes: a prospective study of the vaginal flora in pregnancy. Am J Obstet Gynecol 1984;150:965-72.

19. Offenbacher S, Jared HL, O'Reilly PG, Wells SR, Salvi GE, Lawrence HP, et al. Potential pathogenic mechanisms of periodontitis associated pregnancy complications. Ann Periodontol 1998;3:233-50.

20. Offenbacher S, Katz V, Fertik G, Collins J, Boyd D, Maynor $\mathrm{G}$, et al. Periodontal infection as a possible risk factor for preterm low birth weight. J Periodontol 1996;67:1103-13.

21. Offenbacher S, Medianos PN, Suttle M, Beck JD, Wells S, Lieff $\mathrm{S}$, et al. Elevated human fetal IgM suggests in utero exposure to periodontal pathogens [abstract 2191]. J Dent Res 1999;78:379.

22. Patrick M. Influence of maternal renal infection on the foetus and infant. Arch Dis Child 1967;42(222):208-13.

23. Romero R, Marzo M. Infection and preterm labor. Clin Obstet Gynecol 1988;31:553-84.

24. Rovin S, Costich ER, Gordon AH. The influence of bacteria and irritation in the initiation of periodontal disease in germfree and conventional rats. $J$ Periodontal Res 1966;1:193-204.

25. Sanavi F, Listgarten MA, Boyd F, Sallay K, Nowotny A. The colonization and establishment of invading bacteria in the periodontium of ligature-treated immunosuppressed rats. J Periodontol 1985;56:273-80.

26. Scannapieco FA, Papandonatos GD, Dunford RG. Associations between oral conditions and respiratory disease in a national sample survey population. Ann Periodontol 1998;3:251-6.

27. Soskolne WA. Epidemiological and clinical aspects of periodontal diseases in diabetics. Ann Periodontol 1998;3:3-12.

28. Tesh JM. An approach to the assessment of postnatal development in laboratory animals. In: Neubert D, Merker HJ, Kwasigroch TE. Methods in prenatal toxicology. Evaluation of embryotoxic effects in experimental animals. Stuttgart: Georg Thiene; 1977. p.186-95.

29. Yoshinari N, Kameyama Y, Aoyama Y, Nishiyama H, Noguchi T. Effect of long-term methotrexate-induced neutropenia on experimental periodontal lesion in rats. J Periodontal Res 1944;29:393-400.
Recebido para publicação em 05/07/02 Enviado para reformulação em 06/11/02 Aceito para publicação em 14/02/03 